\begin{tabular}{|c|c|c|c|}
\hline \multirow{2}{*}{$\begin{array}{c}\text { LARUS } \\
\text { Hrvatska akademija } \\
\text { znanosti i umjetnosti }\end{array}$} & 52 & $\begin{array}{c}\text { 7-20 str. } \\
\text { 4 tablice, 3 slike }\end{array}$ & Zagreb 2017 \\
\cline { 2 - 4 } & Prihvaćeno na sjednici Razreda za prirodne znanosti HAZU 19.10.2017. \\
\hline
\end{tabular}

Original scientific paper

\title{
THE NESTING OF THE COMMON RAVEN Corvus corax ON THE ELECTRICITY PYLONS IN THE BARANYA AREA
}

\section{Gniježđenje gavrana Corvus corax na stupovima dalekovoda u Baranji}

\author{
Adrian Tomik \\ I. Meštrovića 74, 31326 Darda, Croatia
}

\begin{abstract}
The Common Raven is a habitat generalist breeding throughout forested and open regions of the Northern Hemisphere. The species has undergone a large increase over the last 40 years in Europe. In the same period, it has begun to nest on pylons of the transmission lines; nowadays, it is a common phenomenon in Europe, including the eastern lowland areas of Croatia. In this study, surveys of the Common Raven nests were conducted on eight power lines in the area of Baranya in Eastern Croatia in 2006 and 2016 respectively. In 2006, 23 active Common Raven nests were found along seven power lines, while in 2016, 37 nests were recorded on eight lines, with a population increase of $60.9 \%$. The average breeding density in 2016 was 3.3 pairs per $10 \mathrm{~km}$ of line, while the average frequency of occupied pylons was $10.2 \%$. The mean distance between neighbouring nests amounted to $3128 \mathrm{~m}$, and the distribution of nests along the power lines was probably affected by food availability. The majority of pylons supporting a Common Raven nest was placed in open agricultural areas $(81.1 \%)$. Power lines proved to be important landscape elements in the avian conservation point of view.
\end{abstract}

Keywords: Common Raven, Corvus corax, nesting, electricity pylons, Baranya, Eastern Croatia.

\section{INTRODUCTION}

The Common Raven (Corvus corax) is a habitat generalist breeding throughout forested and open coastal, steppe, mountain, tundra and cliff regions of the Northern Hemisphere. It nests on cliffs, trees or on artificial structures such as

e-mail: tomikadrian@gmail.com 
electricity pylons, buildings, radio towers, bridges, windmills, etc. The nest is a large and bulky platform. Egg-laying begins in late February over most of its range; the clutch size is typically four to six eggs. It is an opportunistic scavenger, consuming a huge variety of animals and plants (Haraszthy 1998, BirdLife INTERNATIONAL 2017a). The species is mostly sedentary, but northern populations are liable to move southwards in winter (Hagemeijer \& Blair 1997). Between 1980 and 2013, the species underwent a moderate increase in Europe; the global conservation status of the species is currently listed as Least Concern (LC) (BIRDLIFE INTERNATIONAL 2004, 2017b).

The Common Raven is a widespread breeding species in Croatia, occupying a variety of habitats across the country, being the most common in forested and open lowland areas (Kralj 1997, Mikuska et al. 2002, ToмiK unpublished data). In the second part of the $20^{\text {th }}$ century, the species began to nest on pylons of the high-voltage power lines. It is nowadays a well-known phenomenon in the continental part of the country, but the most common in the eastern lowland areas (Grabar 1999, Jurčević-Agić 2006, Bašić-Jakobović 2007). Such tendency has also been registered in other parts of Europe (Stegemann 1971, Molnár 1992, Ratcliffe 1997, Bednorz 2000, Puzović 2007a) as well as in North America (White \& Tanner-White 1988, Steenhof et al. 1993, Kristan \& Boarman 2007) and Asia (Dixon et al. 2013). In the Baranya area, the Common Raven breeds in all forest types as well as in smaller groves, tree lines and even on solitary trees in open agricultural landscape (Томıк unpublished data). The first published data about the nesting of the species on power line pylons in Baranya dates from 1993 (Miкuska \& Miкuska 1994), but the colonisation of pylons probably began in the late 1980s (JurČEvić-Agić 2006).

\section{MATERIALS AND METHODS}

The survey of the Common Raven nests was conducted on eight power lines (of voltage $35 \mathrm{kV}-2 \times 400 \mathrm{kV}$ ) in the area of Baranya in Eastern Croatia. As a part of the Pannonian Basin, the Baranya area $\left(1147 \mathrm{~km}^{2}\right)$ is predominantly a plain with less than $100 \mathrm{~m}$ a.s.l. In the northern part of the area, there is a hill with the peak at $243 \mathrm{~m}$ a.s.l. Baranya is characterized by continental climate; with average precipitation of $642 \mathrm{~mm}$, it is one of the most arid areas of Croatia. The area lies in the Pannonian biogeographical region with the vegetation cover of Pannonian-pontic forest-steppe zone. The alluvial plain makes up about $63 \%$ of the area, including the Kopački rit floodplains between the Danube and Drava rivers. About $48 \%$ of the area is in intensive agricultural use while the forest cover (oak-hornbeam, willow-poplar and mixed forests) makes roughly $20 \%$. There is also a melioration channel network of more than $1000 \mathrm{~km}$ in length (Borovac 2002).

The line transect method was applied during the fieldwork (Bівву et al. 2000), using a bicycle. Observations were performed using a Minox 10x42 binocular 
Table 1. Information about the sections of power lines controlled during the study.

Tablica 1. Podaci o dijelovima dalekovoda koji su provjereni tijekom istraživanja.

\begin{tabular}{|c|c|c|c|c|c|}
\hline Name of the line & $\begin{array}{c}\text { Voltage } \\
(\mathrm{kV})\end{array}$ & Pylon type & $\begin{array}{l}\text { Length } \\
(\mathbf{k m})\end{array}$ & $\begin{array}{c}\text { Ordinal no. } \\
\text { of pylons }\end{array}$ & $\begin{array}{l}\text { No. of } \\
\text { pylons }\end{array}$ \\
\hline Ernestinovo - Pecs* & $2 \times 400$ & A ("bačva") & 22.6 & 58-117 & 60 \\
\hline Valpovo - Beli Manastir & 110 & B (“jela") & 15.2 & $33-75$ & 42 \\
\hline Beli Manastir - Šećerana & 35 & B (“jela") & 4.5 & $1-17$ & 17 \\
\hline $\begin{array}{l}\text { Beli Manastir - Kneževi } \\
\text { Vinogradi }\end{array}$ & 35 & B (“jela") & 8 & $1-28$ & 28 \\
\hline Bilje - Kneževi Vinogradi & 35 & B ("jela") & 13.9 & $4-55$ & 52 \\
\hline Osijek 2 - Beli Manastir & 110 & B ("jela") & 24.5 & $9-87$ & 79 \\
\hline Beli Manastir - Apatin & 110 & B (“jela") & 13.2 & $28-67$ & 40 \\
\hline Kneževi Vinogradi - Gajić & 35 & B (“jela") & 11 & $1-43$ & 43 \\
\hline
\end{tabular}

*The power line "Ernestinovo - Pecs" was surveyed only in 2016

Dalekovod "Ernestinovo - Pecs" provjeren je samo tijekom 2016. godine

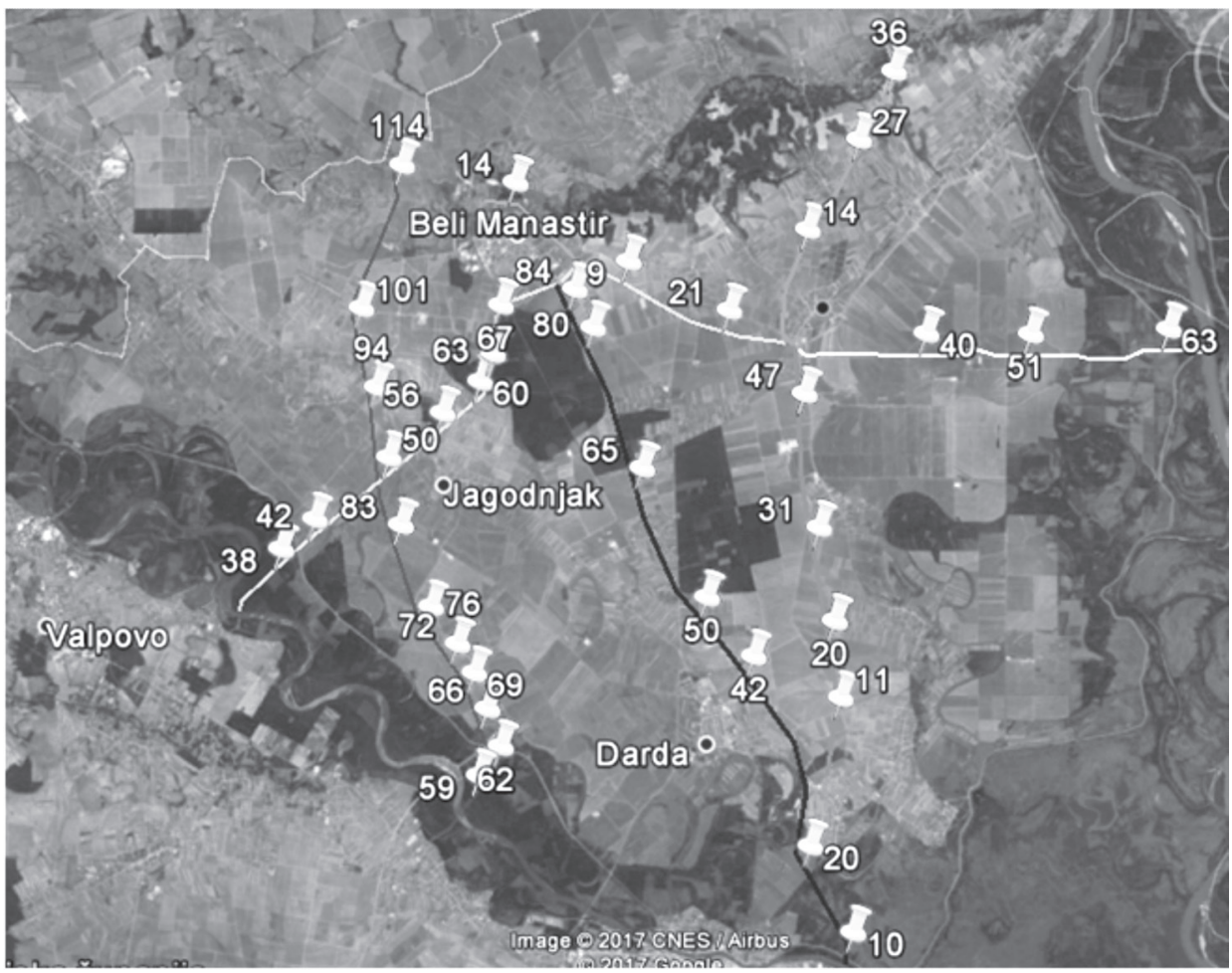

Figure 1. Positions of power lines and distribution of the Common Raven nests in Baranya in 2016. (Source of map: Google $\mathrm{e}^{\mathrm{TM}}$ Earth)

Slika 1. Smještaj dalekovoda i raspored gnijezda gavrana u Baranji tijekom 2016. godine. (Izvor karte: Google ${ }^{T M}$ Earth) 
and a Minox 15-45x zoom telescope. The study area represents the power lines with the surrounding area, which covers most of the Baranya region. The power lines cross various habitats, from closed forest and river floodplains to open agricultural landscapes and rural areas. Information about the type, the voltage, the power line length covered, and the number of surveyed pylons is presented in Table 1. The position of power lines is shown in Figure 1.

Pylons of all power lines found in Baranya are a steel-latticed type. Out of eight lines, seven consist of type B pylons ("jela"), while one consist of type A pylons ("bačva") (Figure 2). All pylons consist of three parts: concrete base and steel "body" and "head". The Common Ravens build their nests on consoles located on the "head" of the pylons. Nests are built on one of three available consoles; thus, upper, middle and lower positions of nests can be distinguished. The average height of occupied pylons in Eastern Croatia is $28.71 \mathrm{~m}$ (JurčEvić-Agić 2006). On every pylon, there is an identification tag with the name of the transmission line and the ordinal number of the pylon.

The fieldwork was carried out in March-April 2006 and in April 2016, respectively. In 2006, only seven power lines existed and were surveyed. Meanwhile, until 2009, a new power transmission line was created in the western part of the area, consisting of type A pylons ("bačva"). The following data were recorded on

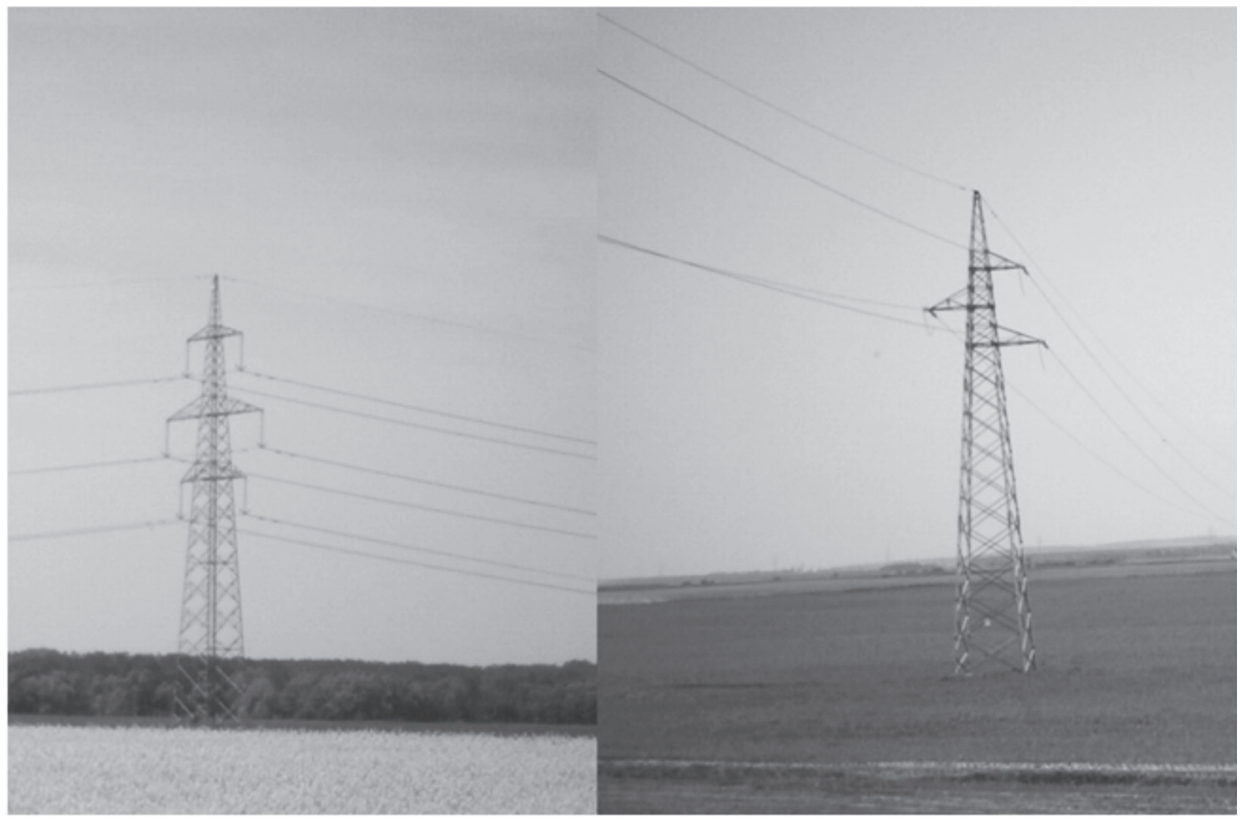

Figure 2. The two pylon types in the Baranya area: left type A („bačva“) and right type B (,jela"). (Photo: A.Tomik)

Slika 2. Dva tipa stupova u Baranji: lijevo tip A („bačva”) i desno tip B („jela“). (foto: A. Tomik) 
the field: the date, the name of the power line, the ordinal number of the pylon supporting an active nest of the Common Raven, the position of the nest on the pylon, the breeding status, the number of chicks (if possible), other comments (if needed). Other bird species nesting on pylons were recorded too, but they were not included in this study. The data were processed using MS Office package and Google Earth program. The positions of active nests were depicted on the map: the breeding density (number of active nests/length of the power line) and the frequency of occupied pylons were also calculated. The distance between neighbouring nests (distance alongside power line) was calculated only for the 2016 study year. In order to identify the conditions affecting the nest-site selection in the year 2016, the habitat structure was defined in the circle of $1 \mathrm{~km}$ around the nests, as well as the distance between the nest and forest edge, and between the nest and nearest settlement edge, respectively, was calculated and averaged. A sample study was conducted in the period from 2006 to 2016 in southern Baranya, in the intensive agricultural area between the villages of Darda and Lug. A standardised survey of two power line sections (pylons nos 30-53 on the line "Osijek 2 - Beli Manastir" and pylons nos 7-33 on the line "Bilje - Kneževi Vinogradi") was carried out on a yearly basis, with the aim of investigating the nest-site fidelity, population trend and nest positions of the breeding Common Ravens.

The change in breeding density and population size between the two study years was determined, as well as the trend of the population. The results of this study were compared with and discussed on the national and worldwide level, using the existing literature on the Common Ravens nesting on pylons. The importance of empty Common Raven nests for other breeding birds was also discussed.

\section{RESULTS}

In 2006, 301 pylons were controlled along seven power lines in the Baranya area and 23 active Common Raven nests were found altogether. All nests were supported by type B pylons ("jela") as no other pylon types existed at that time. With the new power line included, in the 2016 study year, a total of 361 pylons were controlled along eight power lines; 37 active nests were found (Figure 1). Out of these 37 nests, 27 (73\%) were placed on type B pylons ("jela"), while 10 (27\%) were supported by type A pylons ("bačva"). Regarding the position of nests $(n=37), 30$ nests $(81.1 \%)$ were built on the upper console, $6(16.2 \%)$ on the middle console, and one (2.7\%) on the lower console. Considering only the seven power lines surveyed in both study years, there has been an increase of $17.4 \%$ in breeding pairs, from 23 to 27 pairs. With the new power line included, the population increase amounted to $60.9 \%$, from 23 to 37 pairs. Even though, no detailed surveys have been done in the period between 2007 and 2015, based on the results of this study, the long-term trend of the Common Raven population 
nesting on pylons can be defined as increasing. On the majority of power lines, the number of pairs has stabilized between the two study years, and the biggest increase is due to the building of a new transmission line "Ernestinovo - Pecs".

The breeding density of the Common Ravens along the seven power lines in 2006 ranged from 0.75 to 3.9 pairs per $10 \mathrm{~km}$ of line with the average of $2.6 \pm 1$ pairs. For the same seven lines, the density in 2016 ranged from 2.2 to 4.6 pairs per $10 \mathrm{~km}$ of line with the average of $3 \pm 0.9$ pairs. Concerning all power lines, the mean breeding density in 2016 was $3.3 \pm 0.8$ pairs per $10 \mathrm{~km}$ of line (Table 2 ). The frequency of occupied pylons along the seven power lines in 2006 ranged from $2.5 \%$ to $14.3 \%$ with the average of $7.6 \%$. For the same seven lines, the frequency in 2016 ranged from $5.9 \%$ to $16.6 \%$ with the average of $9 \%$. Regarding all power lines, the mean frequency of occupied pylons in 2016 was 10.2\% (Table 2). Accordingly, in the scope of the ten-year period, there has been an increase in the number of breeding pairs of the Common Raven, in the breeding density and in the frequency of occupied pylons. A significant part of the Common Raven population (2016: 17 pairs or $45.95 \%$ ) has nested on the two power lines crossing the western part of Baranya. The highest breeding densities (3.94-4.6) and frequencies of occupied pylons (14.28-16.6), respectively, were also recorded from

Table 2. Number of active nests of the Common Raven, breeding density and frequency of occupied pylons in 2006 and 2016.

Tablica 2. Broj aktivnih gnijezda gavrana, gustoća gniježđenja i zauzetost stupova tijekom 2006. odnosno 2016. godine.

\begin{tabular}{|l|c|c|c|c|c|c|}
\hline & \multicolumn{2}{|c|}{$\mathbf{2 0 0 6}$} & \multicolumn{2}{c|}{$\mathbf{2 0 1 6}$} \\
\cline { 2 - 7 } Name of the line & $\begin{array}{c}\text { No. } \\
\text { of } \\
\text { nests }\end{array}$ & $\begin{array}{c}\text { Frequency } \\
\text { of occupied } \\
\text { pylons (\%) }\end{array}$ & $\begin{array}{c}\text { No. of } \\
\text { breeding } \\
\text { pairs/10 km } \\
\text { of line }\end{array}$ & $\begin{array}{c}\text { No. } \\
\text { of } \\
\text { nests }\end{array}$ & $\begin{array}{c}\text { Frequency } \\
\text { of occupied } \\
\text { pylons (\%) }\end{array}$ & $\begin{array}{c}\text { No. of } \\
\text { breeding } \\
\text { pairs/10 km } \\
\text { of line }\end{array}$ \\
\hline Ernestinovo - Pecs & - & - & - & 10 & 16.6 & 4.42 \\
\hline Valpovo - Beli Manastir & 6 & 14.28 & 3.94 & 7 & 16.6 & 4.6 \\
\hline Beli Manastir - Šećerana & 1 & 5.88 & 2.22 & 1 & 5.88 & 2.22 \\
\hline $\begin{array}{l}\text { Beli Manastir - Kneževi } \\
\text { Vinogradi }\end{array}$ & 2 & 7.14 & 2.5 & 2 & 7.14 & 2.5 \\
\hline Bilje - Kneževi Vinogradi & 4 & 7.69 & 2.87 & 4 & 7.69 & 2.87 \\
\hline Osijek 2 - Beli Manastir & 7 & 8.86 & 2.85 & 7 & 8.86 & 2.85 \\
\hline Beli Manastir - Apatin & 1 & 2.5 & 0.75 & 3 & 7.5 & 2.27 \\
\hline Kneževi Vinogradi - Gajić & 2 & 4.65 & 1.81 & 3 & 6.97 & 2.72 \\
\hline $\begin{array}{l}\text { Total (without } \\
\text { “Ernestinovo - Pecs" ) }\end{array}$ & $\mathbf{2 3}$ & $\mathbf{7 . 6 4}$ & $\mathbf{2 . 5 5}$ & $\mathbf{2 7}$ & $\mathbf{8 . 9 7}$ & $\mathbf{2 . 9 9}$ \\
\hline Total (eight power lines) & & & & $\mathbf{3 7}$ & $\mathbf{1 0 . 2 4}$ & $\mathbf{3 . 2 7}$ \\
\hline
\end{tabular}


those two lines. The minimum, maximum and average distances between neighbouring nests of the Common Raven are presented in Table 3. An overall average distance amounts to $3128 \pm 803.9 \mathrm{~m}$.

Table 3. Distance between neighbouring nests of the Common Raven on seven power lines in 2016.

Tablica 3. Udaljenost između susjednih gnijezda gavrana na sedam dalekovoda tijekom 2016. godine.

\begin{tabular}{|l|c|c|c|}
\hline \multirow{2}{*}{\multicolumn{1}{|c|}{ Name of the line }} & \multicolumn{3}{c|}{ Distance between neighbouring nests $(\mathbf{m})$} \\
\cline { 2 - 4 } & Minimum & Maximum & Average \\
\hline Ernestinovo - Pecs & 1086 & 4945 & 2351 \\
\hline Valpovo - Beli Manastir & 1066 & 3112 & 1840 \\
\hline Beli Manastir - Kneževi Vinogradi & 3631 & 3631 & 3631 \\
\hline Bilje - Kneževi Vinogradi & 2505 & 4347 & 3305 \\
\hline Osijek 2 - Beli Manastir & 1362 & 6763 & 3872 \\
\hline Beli Manastir - Apatin & 3445 & 4522 & 3983 \\
\hline Kneževi Vinogradi - Gajić & 2470 & 3359 & 2914 \\
\hline Total average & - & - & $\mathbf{3 1 2 8}$ \\
\hline
\end{tabular}

During the sample study conducted annually between 2006 and 2016, the number of breeding pairs of the Common Raven (5 pairs) and the distribution of territories along the two power lines remained constant. All pairs changed the nesting pylons between some of the study years, but a certain pair never changed the nest position on the pylon's "head". In $62 \%$ of the cases, the Common Raven pairs did not change the pylon in the following year. Ravens moved to the first nearby pylon in $73.7 \%$ of the cases, and two pylons further in $26.3 \%$ of the cases. Removal to the third or fourth pylon was not noticed. Out of five pairs, only one remained almost completely faithful to one certain pylon. This pair remained faithful to one chosen pylon between 2008 and 2016. During the sample study, two cases of unsuccessful breeding were recorded in the early stages of incubation. In both cases, the pair moved to the first nearby pylon and built a new nest in the same season, while the old nest remained intact. Even though the number of pairs did not change during the study period, presumably there might have been some exchange of birds in certain pairs.

On average, the Common Raven nests were closer to the forest edges than to the nearest settlement edge. Moreover, $62.2 \%$ of all nests were located less than 1 $\mathrm{km}$ from the nearest forest edge, while $40.6 \%$ of the nests were situated less than $1 \mathrm{~km}$ from the nearest settlement edge (Table 4). The majority of pylons supporting a nest were placed in open agricultural areas $(81.1 \%)$, whereas only seven nests $(18.9 \%)$ were found on pylons in a forest environment. 
Table 4. Distances from active Common Raven nests $(n=37)$ to settlement edge and to forest edge in 2016.

Tablica 4. Udaljenosti između gnijezda gavrana ( $n=37$ ) i ruba naselja odnosno ruba šume tijekom 2016. godine.

\begin{tabular}{|c|c|c|c|c|}
\hline \multirow{2}{*}{ Distance scale (m) } & \multicolumn{2}{|c|}{$\begin{array}{c}\text { Distance to settlement } \\
\text { edge }\end{array}$} & \multicolumn{2}{|c|}{$\begin{array}{c}\text { Distance to forest } \\
\text { edge }\end{array}$} \\
\hline & No. of nests & $\%$ & No. of nests & $\%$ \\
\hline $0-1000$ & 15 & 40.55 & 23 & 62.16 \\
\hline $1000-2000$ & 11 & 29.73 & 8 & 21.62 \\
\hline $2000-3000$ & 5 & 13.51 & 6 & 16.22 \\
\hline $3000-4000$ & 5 & 13.51 & - & - \\
\hline $4000-5000$ & 1 & 2.7 & - & - \\
\hline & Minimum & Maximum & \multicolumn{2}{|c|}{ Average } \\
\hline Distance to settlement edge $(\mathrm{m})$ & 310 & 4414 & \multicolumn{2}{|c|}{1679} \\
\hline Distance to forest edge (m) & 10 & 2985 & \multicolumn{2}{|c|}{978} \\
\hline
\end{tabular}

The average share of certain habitat types in the circle of $1 \mathrm{~km}$ around the nest is shown in Figure 3. On average, open agricultural areas were the most common habitat type around the Common Raven nests with a share of about $69 \%$, followed by various forest types and shrubland. The average share of all other habitat types (marshland, settlement, orchard, vineyard, grassland, river) was

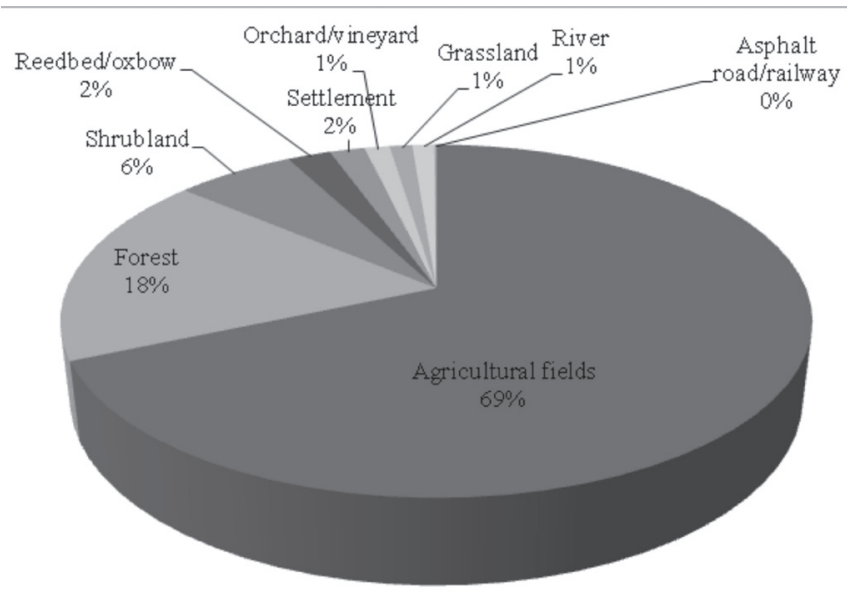

Figure 3. Average share of various habitat types in $1 \mathrm{~km}$ circles around active Common Raven nests $(\mathrm{n}=37)$ in 2016.

Slika 3. Prosječni udio pojedinih tipova staništa u krugu od 1 km oko gnijezda gavrana ( $n=37$ ) tijekom 2016. godine. 
negligible. The two main subtypes of farmland - dry arable land and meliorated arable land with ditches - were evenly distributed in the total share. The highest percentages of certain habitat types in the case of individual nests were as follows: agricultural areas $100 \%$, forest $(77 \%)$, shrubland $(62 \%)$, settlement $(41 \%)$, orchard/vineyard $(19 \%)$, river $(20 \%)$, marshland $(16 \%)$, and grassland $(15 \%)$.

\section{DISCUSSION}

In the current study, the majority of the Common Raven nests (2016: 73\%) were found on steel-latticed type B pylons ("jela"), mostly on the upper console (81\%). A similar situation was found elsewhere in Croatia. In the Đakovo area, in $1997,95.35 \%$ of the nests were supported by steel-latticed type B pylons; $88 \%$ of them were built on the upper position (Grabar 1999). In Eastern Croatia, 72\% of the nests were built on type B and $15.5 \%$ on type A, while about $75 \%$ of the nests were built on the upper position of the pylons (JuRČEvić-Agić 2006).

The breeding density in the Brod-Posavina County amounted to 2.8 pairs per $10 \mathrm{~km}$ of line (BАšı́́-Jаковоvić 2007) in the period 2005-2006, which is similar to the value recorded in the Baranya in the same period. During the study from Eastern Croatia in 1995-2001, the average breeding density increased from 1.6 to 2.5 pairs per $10 \mathrm{~km}$ of line, and the frequency of occupied pylons increased from $5.2 \%$ to $8.3 \%$ (JuRČEvić-Agrć 2006). Considering all the above-mentioned data, the gradual population increase of the Common Raven in Eastern Croatia may be very well tracked through the period 1995-2016. There are very few data available from other parts of Europe or the world. The average number of the Common Ravens nesting on pylons in Poland was 0.6 pairs per $10 \mathrm{~km}$ of line in the years 1996-1998 (Bednorz 2000), while in the States of Idaho and Oregon (USA), it was on average 1.3 pairs per $10 \mathrm{~km}$ of the line (SтеENHof et al. 1993). In the steppe landscape of Mongolia, the density was 1.15 pairs per $10 \mathrm{~km}$ of line (Dixon et al. 2013). Thus, the breeding densities of the Common Raven recorded in Croatia are by far the highest in the world, according to data published until now. The highest average density of all (3.27 pairs per $10 \mathrm{~km}$ of line) was reached in 2016 in the Baranya area.

The distance between the neighbouring Common Raven nests ranged from $1066 \mathrm{~m}$ to $6763 \mathrm{~m}$, on average $3128 \mathrm{~m}$. Thus, the distribution of nests along the power lines was not at all uniform. The minimum distance in the Đakovo area amounted to $848 \mathrm{~m}$, and the total average distance was $2625 \mathrm{~m}$ (Grabar 1999). The distances between the neighbouring nests give some information about the size of the area of activity, as well as indicate the habitat quality. Therefore, smaller distances probably indicate areas rich in food, able to support more Common Ravens. Accordingly, the smallest average distances during 2016 were recorded from the two power lines, crossing the western part of Baranya with floodplain forests and mosaic agricultural habitats providing a good food supply. The high- 
est breeding densities (3.9-4.6 pairs/10 km) and frequencies of occupied pylons $(14.3 \%-16.6 \%)$, respectively, were also recorded from those two lines. Nest distribution was significantly affected by food availability in other parts of Eastern Croatia (Jurčević-Agić 2006), and in Poland (Bednorz 2000), with the majority of nests recorded in the vicinity of farms, slaughterhouses, communal waste dumps and near heavy-traffic roads. Unlike these studies, the distributional pattern of the Common Ravens in Baranya was generally not affected by the above-mentioned structural elements, since farms and slaughterhouses have been modernized, representing no food source anymore. The only exception was the illegal garbage dump nearby the "Valpovo - Beli Manastir" line, which was probably the main reason for the highest breeding density recorded in Baranya.

Similarly as in this study, KNIGHT et al. (1995) suggested that land-use patterns influence food availability and the Common Raven numbers, with a greater abundance of breeding birds found in suburban irrigated farmlands. According to other studies (Engel \& Young 1989, Nogales \& Hernandez 1994, Rösner et al. 2005), the animal component is essential in the diet of the Common Ravens. This is probably the case in Baranya, too, since adult Common Ravens carrying rodents or eggs, feeding on roadkills and foraging on garbage dumps or along freshly "cleaned" ditches were observed during April 2016.

In the Baranya area, $81.1 \%$ of all nests were built on pylons in open farmlands, while the rest of the nests were found along forest edges. The Common Ravens were distributed mainly in open farmland areas in other parts of Eastern Croatia, too (Grabar 1999, Jurčević-Agić 2006). In Poland, the Common Ravens also preferred farmlands, as $95.4 \%$ of their nests were built on pylons in open man-made landscape (Bednorz 2000). During the study in North America, most of the Common Ravens were breeding in irrigated farmlands (KNIGHT et al. 1995), while in Mongolia, they were found in open steppe habitats (Dixon et al. 2013).

The population trend of the Common Ravens breeding on pylons in Baranya area seems to be still increasing, but considering single power lines, the number of pairs is more or less stable, with no decrease recorded at all. During the period 1995-1997, a significant population increase was recorded on six power lines in the Đakovo area, with a growth of 207.1\% (Grabar 1999). A similarly large increase occurred on 23 power lines in Eastern Croatia from 1995 to 2001 (JurčEvić-Agrć 2006). Evidently, the intensive colonisation of pylons by the Common Raven occurred in Eastern Croatia in the late 1990s; this phenomenon is still ongoing, even though the population has more or less become stabilized by 2016. However, new power line constructions can still trigger further population increase, as the case of the new line "Ernestinovo - Pecs" showed. The Common Raven still breeds both on trees in forests and in open habitats. Given that those territories have already been occupied and the ongoing forest cuttings lead to further habitat loss, the power lines, especially the new ones, represent an excel- 
lent opportunity for the nesting of young Common Raven pairs. The primary triggering factor of the power line colonisation both in Croatia and in other countries in Europe was undoubtedly the recovery and large increase of the Common Raven populations in the period 1970-1990 (BirdLife InTERnational 2004), as well as the still ongoing moderate increase recorded in the period 1990-2010 (PECBMS 2007; 2010).

During the sample study of the Common Raven breeding in the highly intensive agricultural landscape, the long-term population trend in this area was found stable. It seems that this local population had stabilized at the beginning of the century. The Common Raven pairs are faithful to their territory, but they are not faithful to one chosen pylon. A similar situation was recorded in Eastern Croatia in the period 1995-2001, where the majority of pairs had switched the pylons in the following year (to the first nearby pylon in $66 \%$ of cases, and to the second pylon in $25 \%$ of cases) (Jurčević-Agrć 2006). Unlike this, the Common Ravens breeding in Poland are much more faithful to their once-chosen pylons (BEDNorz 2000).

Since electric power lines, and especially medium-voltage pylons, are known as a source of avian mortality (Ferrer et al. 1991, Bevanger 1994, GuYonne et al. 2001, Rubolini et al. 2005, Prinsen et al. 2011), the power lines have generally been considered as negative elements of the landscape. On the other hand, however, high-voltage pylons have become alternative nesting places for a number of bird species, including raptors and corvids (Brown \& Lawson 1989, Infante \& Peris 2003, Puzović 2007a; 2007b, Prinsen et al. 2011, Mainwaring 2015). The Common Ravens living in a man-made landscape are capable of population increase and distributional changes, in response to the creation of new structural elements (KNIGHT et al. 1995). The power lines are especially important factors in highly intensive farmland areas, where often no other available places for nesting can be found (ТRујаNowsкi et al. 2014, Томік unpublished data). In Eastern Croatia corvids, mainly the Hooded Crows Corvus cornix and the Common Ravens are the most numerous breeders of electric pylons. In intensive agricultural areas of Baranya and Slavonia, the empty nests of corvids are also crucial for the breeding of falcons, which do not build their own nests (Tомгк unpublished data). Thus, the presence of high-voltage power lines can be of avian conservation interest, including some high-priority species, like the Saker Falcon Falco cherrug (BAgYura et al. 2004, Puzović 2008, Dixon 2009, Rajković 2013).

\section{References}

Bagyura, J., Szitta, T., Haraszthy, L., Demeter, I., Sandor, I., Dudas, M., Kallay, G., ViszLo, L. (2004): Population trend of the Saker Falcon Falco cherrug in Hungary between 1980 and 2002. pp. 663-672 In: Chancellor, R. D. \& Meyburg B.-U. (eds): Raptors Worldwide. WWGBP/MME. 
BАšıć-Jаковоvić, A. (2007): Gniježđenje gavrana Corvus corax na stupovima dalekovoda na području Brodsko-posavske županije. Magistarski rad. Prorodoslovno-matematički fakultet, Zagreb.

Bednorz, J. (2000): Ravens Corvus corax Linnaeus, 1758, nesting on electricity pylons in the Wielkopolska region. Acta zool. Cracov. 43: 177-184.

Bevanger, K. (1994): Bird interactions with utility structures - collision and electrocution, causes and mitigating measures. Ibis 136: 412-425.

Bibby, C.J., Burgess, N.D., Hill, D.A. (2000): Bird Census Techniques. Academic Press, London, $2^{\text {nd }}$ edition.

Birdlife International (2004): Birds in Europe: population estimates, trends and conservation status. Cambridge, UK: BirdLife International (Conservation Series No. 12)

Birdlife International (2017a): Species factsheet: Corvus corax. Downloaded from http:// www.birdlife.org on 10/07/2017.

Birdlife International (2017b): Corvus corax. (amended version published in 2016) The IUCN Red List of Threatened Species 2017: e.T22706068A113271893. Downloaded from http://dx.doi.org/10.2305/IUCN.UK.2017-1.RLTS.T22706068A113271893.en. on 10/07/2017.

Borovac, I. (2002): Veliki atlas Hrvatske. Mozaik knjiga, Zagreb.

Brown, CJ. \& Lawson, J. (1989): Birds and electricity transmission lines in south west Africa/Namibia. Madoqua 16: 59-67.

Dixon, A. (2009): Saker Falcon breeding population estimates. Part 2. Asia. Falco 33: 4-10.

Dixon, A., Purev-Ochir, G., Galtbalt, B., Batbayar, N. (2013): The Use of Power Lines by Breeding Raptors and Corvids in Mongolia: Nest-Site Characteristics and Management Using Artificial Nests. Journal of Raptor Research 47: 282-291.

Engel, K.A. \& Young, L.S. (1989): Spatial and temporal patterns in the diet of common ravens in southwestern Idaho. Condor 91: 372-378.

Ferrer, M., De La Riva, M., Castroviejo, J. (1991): Electrocution of raptors on power lines in Southern Spain. J. Field Ornithol. 62: 54-69.

Grabar, M. (1999): Gniježđenje vrane gavrana, Corvus corax, na području Đakova. Diplomski rad. Pedagoški fakultet, Osijek.

Guyonne, F., Janss, E., Ferrer, M. (2001): Avian electrocution mortality in relation to pole design and adjacent habitat in Spain. Bird Conservation International 11: 3-12.

Hagemeijer, E.J.M. \& Blair, M.J. (1997): The EBCC atlas of European breeding birds: their distribution and abundance. T. \& A. D. Poyser, London.

Haraszthy, L. (1998): Holló (Corvus corax). Pp. 358-359 In: Haraszthy, L. (ed.): Magyarország madarai [Birds of Hungary]. Mezőgazda Kiadó, Budapest.

Infante, O. \& Peris, S. (2003): Bird nesting on electric power supports in northwestern Spain. Ecological Engineering 20: 321-326.

JurČEvić-Agić, I. (2006): Ravens, Corvus corax (L. 1758), nesting on high-voltage transmission line pylons in Croatia. Belgian Journal of Zoology 136: 167-171.

Knight, R.L., Knight, H.A.L., Camp, R.J. (1995): Common ravens and number and type of linear rights-of-way. Biological Conservation 74: 65-67.

KraLJ, J. (1997): Ornitofauna Hrvatske tijekom posljednjih dvjesto godina. Larus 46: 1-112.

KRISTAN, W.B. III \& BoARMAN, W.I. (2007): Effects of anthropogenic developments on common raven nesting biology in the west Mojave Desert. Ecological Applications 17: 1703-1713. 
Mainwaring, M.C. (2015): The use of man-made structures as nesting sites by birds: A review of the costs and benefits. Journal for Nature Conservation 25: 17-22.

Mikuska, J. \& Mikuska, T. (1994): Breeding of the Raven on transmission-line pylon. Troglodytes 7: 74-75.

Mikuska, J., Mikuska, T., Romulić, M. (2002): Ptice, Vodič kroz biološku raznolikost Kopačkog rita. Matica hrvatska, Osijek.

Molnár, A. (1992): Holló (Corvus corax) költése magasfeszültségű távvezeték tartóoszlopán. Madártani tájékoztató 1(jan-jún): 15.

PECBMS (2007): State of Europe's Common Birds, 2007. CSO/RSPB, Prague, Czech Republic.

PECBMS (2010): Population Trends of European Common Birds, 2010. CSO/RSPB, Prague, Czech Republic.

Prinsen, H.A.M., Boere, G.C., Pires, N., Smallie, J.J. (2011): Review of the conflict between migratory birds and electricity power grids in the African - Eurasian region. CMS Technical Series No. XX, AEWA Technical Series No. XX. Bonn, Germany.

Puzović, S. (2007a): Dalekovodi kao strukturni faktor staništa ptica. Doktorska Disertacija. Novi Sad.

Puzović, S. (2007b). Gnežđenje ptica na visokonaponskim dalekovodima u Srbiji. Zaštita prirode 58(1-2): 141-155.

Puzović, S. (2008): Nest occupation and prey grabbing by saker falcon (Falco cherrug) on power lines in the province of Vojvodina (Serbia). Archives of Biological Science, Belgrade 60: 271-277.

Rajкоvić, D. (2013): Distribution, numbers and nest site choice of Saker Falcon Falco cherrug in Vojvodina Province (N Serbia). Ciconia 22/23: 39-42.

Ratcliffe, D. (1997): The Raven. T. \& A.D. POYSER, London.

Rösner, S., Selva, N., Müller, T., Pugacewicz, E., Laudet, F. (2005): Raven Corvus corax ecology in a primeval temperate forest. pp. 385-405. In: JerzaK, L., Kavanagh, B.P., Tryjanowski, P. (eds.): Ptaki krukowate Polski [Corvids of Poland]. Bogucki Wyd. Nauk., Poznañ.

Rubolini, D., Gustin, M., Bogliani, G., Garavaglia, R. (2005): Birds and powerlines in Italy: an assessment. Bird Conserv. Int. 15: 131-145.

Steenhof, K., Kochert, M.N., Roppe, J.A. (1993): Nesting by raptors and common ravens on electrical transmission line towers. J. Wildl. Manage. 57(2): 271-281.

Stegemann, K.D. (1971): Kolkrabenbrut auf einem Hochspannungsmast in der Friedländer Grossen Wiese. Falke 18(2): 62-63.

Tryjanowski, P., Sparks, T., Jerzak, L., Rosin, Z.M., SkóRKa, P. (2014): A paradox for conservation: Electricity pylons may benefit avian diversity in intensive farmland. Conservation Letters 7(1): 34-40.

White, C.M. \& TANner-White, M. (1988): Use of interstate highway overpasses and billboards for nesting by the Common Raven (Corvus corax). The Great Basin Naturalist 48: 64-66. 


\section{SAŽETAK}

Gavran nastanjuje raznolika šumska i otvorena staništa širom sjeverne polutke. Tijekom posljednjih 40 godina populacija vrste u Europi je značajno porasla i istovremeno su se počeli gnijezditi na stupovima dalekovoda. Danas je ova pojava opće poznata po Europi, Sjevernoj Americi i Aziji, uključujući i istočne ravničarske krajeve Hrvatske. Prvi slučaj gniježđenja gavrana na stupu dalekovoda zabilježen je krajem 80-tih godina 20. stoljeća u Istočnoj Slavoniji. Ovaj rad prikazuje rezultate istraživanja gavrana koji se gnijezde na osam linija dalekovoda na području Baranje. Tijekom 2006. godine na ukupno sedam dalekovoda zabilježeno je gniježđenje 23 para gavrana, dok je 2016. godine na osam dalekovoda nađeno ukupno 37 aktivnih gnijezda. Velik porast populacije (60,87\%) uzrokovan je gradnjom novog dalekovoda čije su stupove gavrani vrlo brzo zauzeli. Na većini ostalih dalekovoda populacija gavrana se stabilizirala. Prosječna gustoća gniježđenja tijekom 2016. godine dosegla je 3,27 parova/10 km dalekovoda što je najveća dosad zabilježena gustoća u Europi i svijetu. Prosječna zauzetost stupova tijekom 2016. godine bila je 10,24\%, dok je srednja udaljenost između susjednih gnijezda iznosila $3128 \mathrm{~m}$. Raspored gnijezda na dalekovodima nije ujednačen, već vrlo vjerojatno ovisi o mozaičnosti staništa i sukladno tome, o količini raspoložive hrane. Kao i drugdje u svijetu, u Baranji je većina gnijezda nađena na stupovima smještenim na otvorenim poljoprivrednim staništima $(81,08 \%)$.

Iako dalekovodi često uzrokuju ugibanje ptica putem sudara ili elektrokucije, njihovi stupovi mnogim vrstama također predstavljaju važna alternativna mjesta za gradnju gnijezda, čime doprinose povećanju bioraznolikosti, osobito u intenzivno obrađivanim poljoprivrednim područjima. Gavrani i sive vrane najčešće su gnjezdarice stupova u Hrvatskoj, a njihova prazna gnijezda često zauzimaju vjetruše i sokolovi lastavičari, te ponekad stepski sokolovi. Stoga, dalekovodi svakako imaju važnu ulogu u zaštiti i opstanku strogo zaštićenih grabljivica te je potrebno posvetiti više pažnje njihovom redovitom istraživanju. 